\title{
Penerapan Ragam Pola Agroforestri Terhadap Pendapatan dan Cadangan Karbon di Kawasan Hutan Sesaot Lombok Barat
}

\section{Application of Various Agroforestry Patterns on Revenues and Carbon Stocks in Sesaot Forest Areas West Lombok}

\author{
Markum*, Andy C. Ichsan, Maiser Saputra, M. Rifky Tirta Mudhofir \\ Jurusan Kehutanan Fakultas Pertanian Universitas Mataram \\ *Corresponding Author Email: markum.exp@unram.ac.id
}

Manuscript received: 08-12-2020. Accepted: 25-10-2021

\begin{abstract}
ABSTRAK
Kawasan hutan Sesaot telah dikelola oleh masyarakat melalui skema Perhutanan Sosial dengan sistem agroforestri. Tujuan penelitian adalah mengidentifikasi keragaman pola agroforestri, menganalisis pendapatan pada ragam pola agroforestri, menganalisis jumlah cadangan karbon dan menganalisis pola agroforestri yang paling optimal. Metode yang digunakan deskriptif melalui serangkaian observasi, wawancara dan Focus Group Discussion, kepada 42 responden dan pengukuran cadangan karbon di 18 lokasi petani. Analisis pola agroforestri dilakukan dengan pembuatan klaster berdasarkan dominasi tanaman, analisis jumlah carbon digunakan persamaan allometrik dan analisis nilai optimal pola agroforestri menggunakan skoring. Berdasarkan hasil penelitian dapat disimpulkan bahwa: terdapat empat pola agroforestri di Kawasan Hutan Sesaot, yaitu, agroforestri dominan kemiri, agroforestry dominan mahoni, agroforestri campuran dan agroforestri sederhana. Pendapatan terbesar diperoleh pada pola agroforestry campuran dan terkecil pada dominan mahoni. Sedangkan jumlah cadangan karbon terbesar terdapat pada dominan mahoni dan terkecil pada agroforestri sederhana. Hasil analisis skoring menunjukkan bahwa praktik agroforestry campuran termasuk kategori paling optimal dibandingkan dengan pola agroforestry yang lain.
\end{abstract}

Kata kunci: pola; agroforestri; pendapatan; cadangan; karbon

\begin{abstract}
The Sesaot forest area has been managed by the community through the Social Forestry scheme with an agroforestry system. The objectives of the study were to identify the diversity of agroforestry patterns, analyze incomes on various agroforestry patterns, analyze the amount of carbon stock and analyze the most optimal agroforestry patterns. The method used is descriptive through a series of observations, interviews and Focus Group Discussions, to 42 respondents and measurement of carbon stocks in 18 farmer locations. Analysis of agroforestry patterns was carried out by making clusters based on plant dominance, analyzing the amount of carbon using allometric equations and analyzing the optimal value of agroforestry patterns using scoring. Based on the results of the study, it can be concluded that: there are four agroforestry patterns in the Sesaot Forest Area, namely, candlenut
\end{abstract}


dominant agroforestry, mahogany dominant agroforestry, mixed agroforestry and simple agroforestry. The largest income was obtained in the mixed agroforestry pattern and the smallest was in the mahogany dominant. Meanwhile, the largest amount of carb on stock was found in the mahogany dominant and the smallest was in the simple agroforestry. The results of the scoring analysis show that mixed agroforestry practices are in the most optimal category compared to other agroforestry patterns.

Keywords: agroforestry; pattern; income; carbon; stock

\section{PENDAHULUAN}

Kawasan Hutan Sesaot berada di wilayah hulu Daerah Aliran Sungai (DAS) Jangkok, mencakup kawasan hutan lindung seluas 3.042 ha. Kawasan hutan ini telah mengalami perubahan tutupan hutan yang masif terjadi sejak tahun 2000 -2005 akibat penebangan illegal (Muktar, 2011). Sejalan dengan hal tersebut, berdasarkan hasil interpretasi Citra Landsat 5 TM di Kawasan tersebut, telah terjadi penurunan tutupan hutan primer sebanyak $22 \%$ sejak 1995-2010 (Markum et al., 2013; Tratib, 2011). Perubahan tutupan hutan primer tersebut beralih menjadi hutan sekunder dengan beragam sistem penggunaan lahan, diantaranya adalah penggunaan sistem agroforestri.

Perubahan tutupan hutan tersebutberhubungan dengan berbagai aktivitas manusia yang terkait dengan adanya praktik-praktik pengelolaan hutan oleh masyarakat dan lahirnya beberapa produk kebijakan dari pemerintah daerah maupun pemerintah pusat (Tjakrawarsa et al.,2009). Namun tidak semua perubahan hutan menjadi penggunaan untuk agroforestri buruk, karena dalam banyak kasus praktik agroforestri telah membuktikan perannya sebagai penyangga hutan. Dalam hal ini agroforestri mampu berperan menjaga keanekaragaman hayati, menekan laju limpasan permukaan dan menjaga cadangan karbon (Hairiah et al., 2020; Prayitno dan Wasmat, 2001; Rahayu dan Harja., 2012; van Nordwijk et al., 2004).

Hasil penelitian (Markum et al., 2014) di Kawasan Hutan Sesaot menunjukkan bahwa sistem agroforestri dengan kerapatan tanaman di atas 900-1.100 individu/ha, mampu mempertahankan nilai indeks keanekaragaman spesies 2,4, mempertahankan limpasan permukaan pada angka $6 \%$ dan mempertahankan cadangan karbon 170 ton/ha. Nilai tersebut menunjukkan bahwa agroforestri memiliki peran yang baik dalam menjaga kualitas lingkungan.Selain berperan penting dalam aspek lingkungan, agroforestri juga telah terbukti mampu memberikan kontribusi ekonomi bagi masyarakat (Markum et al., 2004). Kasus di beberapa tempat di Pulau Lombok, dengan pemberian lahan kelola rata-rata 0,35 ha kepada masyarakat di sekitar hutan, ada tambahan pendapatan petani kisaran Rp 600.000-Rp 900.000 setiap bulan, tergantung pada keragaman tanaman yang dikelola oleh petani.

Sistem pengelolaan lahan di Kawasan Hutan Sesaot didasarkan atas pemberian izin melalui skema izin Perhutanan Sosial (PS) adalah pemanfaatan hutan oleh masyarakat ditujukan untuk memberdayakan masyarakat setempat. Program PS merupakan langkah kompromi yang strategis dalam pelestarian hutan dan peningkatan pendapatan masyarakat, khususnya di sekitar kawasan hutan (Permen LHK No. 83 tahun 2016). Prinsip penerapan PS adalah memberikan akses kelola hutan kepada masyarakat dengan tujuan meningkatkan kesejahteraan masyarakat dengan tetap menjaga fungsi hutan sebagai penyangga lingkungan setempat (Suradirja et al., 2018). Dengan demikian pemberian izin skema PS dalam jangka pendek maupun jangka panjang diharapkan dapat meningkatkan produktivitas tanaman, 
perbaikan tata guna lahan, memperbaiki iklim mikro, dan meningkatkan jumlah cadangan karbon.

Nilai cadangan karbon adalah salah satu instrumen yang digunakan untuk mengetahui kondisi hutan. Semakin tinggi cadangan karbon di hutan, menandakan bahwa tutupan vegetasi semakin rapat, biomasa tanaman semakin besar, atau dengan kata lain kondisi hutan semakin baik (Cabezas dan Nathaniel, 2008; Fahmudin, 2004; Hairiah et al., 2002). Oleh karena itu cadangan karbon salah satu informasi yang digunakan untuk evaluasi kinerja hutan di tingkat daerah, nasional maupun global, oleh lembaga-lembaga kredibel antara lain Kementerian Kehutanan, ICRAF, CIFOR, IPCC dan Bank Dunia (IFCA, 2008).

Pemberian izin PS di Kawasan Hutan Sesaot adalah seluas 185 ha yang tersebar di 3 desa yaitu Desa Sesaot, Desa Lebah Sempage dan Desa Sedau. Lokasi PS berada di kawasan hutan lindung.Pemegang Izin PS adalah Kelompok Masyarakat Pelestari Hutan (KMPH) berdasarkan Surat Keputusan Bupati Lombok Barat Nomor 2130/65/Dinhut/2009, tentang Izin Pemanfaatan Hasil Hutan Kemasyarakatan (IUPHKm) dengan jumlah penerima manfaat sebanyak 1.224 petani penggarap.

Dalam praktiknya masyarakat mengelola lahan PS dengan menerapkan sistem agroforestri (Markum et al., 2014; Markum et al, 2014; Muktar, 2011).Penerapan sistem agroforestri oleh masyarakat cukup beragam, ditandai dengan keragaman jenis vegetasi, keragaman struktur tanaman, keragaman spesies vegetasi bawah tegakan, dan keragaman kerapatan tanaman. Adanya keragaman penerapan pola agroforestri tersebut tentu berdampak terhadap ragam pendapatan dan ragam nilai cadangan karbon.

Praktik agroforestri yang baik adalah jika hasilnya mampu memberikan nilai tinggi untuk pendapatan masyarakat dan nilai cadangan karbon (Hairiah et al., 2006 ). Keragaman pola agroforestri yang diterapkan oleh masyarakat di Kawasan Hutan Sesaot tentu juga bervariasi dalam menghasilkan pendapatan dan cadangan karbon.Tantangan pengelolaan agroforestri di tingkat masyarakat adalah mendapatkan pilihan, pola mana yang dinilai paling optimal memberikan manfaat ekonomi dan lingkungan, sehingga praktik dengan sistem agroforestri dapat berhasil guna dan berkelanjutan. Tujuan penelitian ini adalah untuk mengidentifikasi keragaman pola agroforestri, menganalisis pendapatan pada ragam pola agroforestri, menganalisis jumlah cadangan karbon dan menganalisis pola agroforestri yang paling optimal.

\section{METODE}

Metode yang digunakan dalam penelitian ini adalah metode deskriptif, merupakan metode untuk mengeksplorasi mengenai suatu fenomena atau kenyataan sosial yang ada saat ini dengan cara mendeskripsikan variabel yang berkaitan dengan masalah yang ingin diteliti, menganalisis dan menarik kesimpulan (Faisal, 2010).Jenis data yang digunakan adalah data kualitatif dan data kuantitatif.

\section{Responden}

Responden dalam penelitian ini adalah petani yang tergabung dalam Kelompok Masyarakat Pelestari Hutan (KMPH). Lokasi desa yang diambil adalah Desa Lebah Sempage, ditentukan secara puposive sampling atas dasar lokasi desa tersebut memiliki data jumlah petani yang jelas yang dibagi dalam 3 blok. Total jumlah petani di Lebah Sempage 
adalah 74 orang. Penentuan jumlah responden menggunakan rumus Slovin dengan tingkat kesalahan10 \%. Berikut perhitungan penarikan sampel menggunakan rumus Slovin:

$$
n=\frac{N}{N \cdot d^{2}+1}
$$

Keterangan:

$\mathrm{n}=$ Ukuran sampelN= Ukuran populasi $(74) \mathrm{d}=$ Galat pendugaan $(10 \%)$

Berdasarkan rumus Slovin tersebut, maka jumlah responden sebanyak42 orang.

\section{Teknik Pengumpulan Data}

Teknik yang digunakan adalah observasi, wawancara dengan instrument kuisioner, pengukuran dan verifikasi lapang. Untuk memastikan informasi hasil wawancara konsisten dengan dengan kondisi dilapangan, maka akan dilakukan verifikasi dan pengukuran pada lahan petani. Kegiatan verifikasi lahan dilakukan pada lahan petani, pada masing-masing blok sebanyak 6 petani, sehingga total ada 18 lokasi. Hal tersebut dilakukan guna memperkecil bias pada data yang akan dihasilkan antara wawancara dengan kondisi faktual di lapangan. Teknik pengambilan data untuk pengukuran cadangan karbon menggunakan teknik sampling plot ukuran $20 \mathrm{~m}$ x $20 \mathrm{~m}$ untuk ukuran pohon, ukuran plot $10 \mathrm{~m}$ x $10 \mathrm{~m}$ untuk ukuran tiang, dan ukuran plot $5 \mathrm{~m}$ x $5 \mathrm{~m}$ untuk ukuran pancang.

Tabel 1. Pengukuran sampling plot

\begin{tabular}{llcc}
\hline No. & \multicolumn{1}{c}{ Ukuran Plot } & $\begin{array}{c}\text { Jumlah Lokasi } \\
\text { (petani) }\end{array}$ & Jumlah Plot \\
\hline 1 & $20 \mathrm{~m} \times 20 \mathrm{~m}$ & 6 & 18 \\
2 & $10 \mathrm{~m} \times 10 \mathrm{~m}$ & 6 & 18 \\
3 & $5 \mathrm{~m} \times 5 \mathrm{~m}$ & 6 & 18 \\
\hline & Jumlah & 18 & 54 \\
\hline
\end{tabular}

Dasar pengambilan 18 plot adalah untuk untuk mewakili 9,5\% dari total luas lahan petani sebanyak 42 responden. Luas rata-rata lahan petani adalah 0,3 ha, sehingga dengan pengambilan 18 plot ukuran terbesar $20 \mathrm{~m}$ x $20 \mathrm{~m}$ adalah $(12.000 \mathrm{~m} 2 / 126.000 \mathrm{~m} 2) \times 100 \%=$ 9,5\%, dari luas total 126.000 ha. Sketsa plot adalah sebagai berikut (Gambar 1).

\section{Variabel Penelitian}

(1) untuk mengidentifikasikeragaman pola agroforestri, variabel yang diteliti meliputi : nama spesies tanaman, jumlah tanaman, pengelompokkan tanaman berdasarkan jenis kayu dan non kayu dan menyusun pola agroforestri berdasarkan dominasi jenis tanaman tegakan utama; (2) untuk menganalisis pendapatan petani variabel yang diteliti meliputi: biaya input produksi, jumlah produksi semua jenis tanaman, harga produksi semua jenis tanaman dan nilai produksi ; (3) untuk menganalisis jumlah cadangan karbon, variabel yang diteliti adalah: mengukur semua jenis tanaman yang memiliki diameter ( $\mathrm{dbh}=$ diameter setinggi dada) di atas $5 \mathrm{~cm}$, dan mengelompokkan berdasarkan ukuran pancang $(\mathrm{dbh} 5-10 \mathrm{~cm})$, tiang $(\mathrm{dbh}>10-20$ $\mathrm{cm}$ ) dan pohon $(>20 \mathrm{~cm}$ ), mengukur tinggi tanaman, diukur sampai ketinggian pada cabang terendah; (4)untuk menganalisis pola agroforestri yang optimal, variabel yang diteliti adalah: nilai pendapatan untuk masing-masing pola agroforestry dan jumlah cadangan karbon untuk masing-masing pola agroforestri 


\section{Analisis Data}

Penentuan pola agroforestridigunakan analisis deskriptif dengan mengkategorikan pola kombinasi tanam dan ragam tanaman MPTS (Multi Purpose Trees Species) yang dominan; pengukuran pendapatan dihitung hanya yang berasal dari hasil pengelolaan hutan khusus hasil hutan bukan kayu (Soekartawi, 2005), karena fungsi hutan di Sesaot adalah hutan lindung yang tidak boleh dimanfaatkan kayunya; analisis estimasi jumlah cadangan karbon menggunakan persamaan alometrik sebagai berikut:

Tabel 2: Alometrik Equation yang digunakan pada perhitungan karbon pohon

(Sumber Hairiah et al, 2011).

\begin{tabular}{lll}
\hline Jeni pohon & Estimasi biomassa pohon, $\mathrm{Kg} /$ pohon & Sumber \\
\hline Pohon bercabang & $\mathrm{BK}=0,11 \rho \mathrm{D}^{2,62}$ & Katterings, 2001 \\
Pohon tidak bercabang & $\mathrm{BK}=\pi \rho \mathrm{H} \mathrm{D}^{2,08}$ & Hairiah et al, 1999 \\
Pisang & $\mathrm{BK}=0.030 \mathrm{D}^{2,13}$ & Arifin, 2001, Van Noordwijk, \\
& & 2002 \\
Palem & $\mathrm{B}=\exp (-2.134+2.530 \times \ln (\mathrm{D}))$ & Brown, 1997 \\
Kopi dipangkas & $\mathrm{B}=0.281 \mathrm{D}^{2.06}$ & Arifin,2001;Van Noordwijk,2002 \\
Kakao & $\mathrm{B}=0.1208 \mathrm{D}^{1.98}$ & Yuliasmara et al., 2009 \\
\hline
\end{tabular}

Keterangan:

$\mathrm{B}=$ Berat Kering $\left(\mathrm{kg} /\right.$ pohon $\left.^{-1}\right)$,

$\rho=$ Kerapatan atau berat jenis kayu $\left(\mathrm{Mg} \mathrm{M}^{-3}, \mathrm{kgdm}^{-3}\right.$ atau $\left.\mathrm{gr} \mathrm{cm}^{-3}\right)$,

$\mathrm{D}=$ Diameter $(\mathrm{cm})$ setinggi dada $(1.3 \mathrm{~m})$,

Total biomasa $=\mathrm{BK}_{1}+\mathrm{BK}_{2}+\mathrm{BK}_{3}+\ldots . . . \mathrm{BK}_{\mathrm{n}}$

Untuk Analisis pilihan pola agroforestri yang optimal digunakan skoring dengan mempertimbangkan besaran pendapatan dan jumlah cadangan karbon, sebagai berikut:

Tabel 3. Penilaian skor untuk pendapatan

\begin{tabular}{lcc}
\hline $\begin{array}{l}\text { Kisaran Pendapatan } \\
(\text { Rp/tahun/ha) }\end{array}$ & Kriteria & Keterangan Nilai Skor \\
\hline $1 .<5.400 .000$ & Buruk & 10 \\
$2 .>5.400 .000-16.200 .000$ & Cukup & 30 \\
$3 .>16.200 .000-27.000 .000$ & Baik & 60 \\
$4 .>27.000 .000$ & Sangat baik & 100 \\
\hline
\end{tabular}

Keterangan: Pendekatan menggunakan standar penghasilan minimal (Bappenas, 2018), minimal setiap orang berpenghasilan US \$ 1 per hari. Ukuran standar setiap orang adalah $\mathrm{Rp} 5.400 .000 /$ orang/tahun.

Tabel 4. Penilaian skor untuk hasil estimasi cadangan karbon

\begin{tabular}{|c|c|c|}
\hline $\begin{array}{l}\text { Kisaran Jumlah Cadangan Karbon } \\
(\mathrm{Mg} / \mathrm{ha})\end{array}$ & Kriteria & Keterangan Nilai Skor \\
\hline 1. $<30$ & Buruk & 10 \\
\hline 2. $>30-70$ & Cukup & 30 \\
\hline 3. $>70-110$ & Baik & 60 \\
\hline 4. $>110$ & Sangat baik & 100 \\
\hline
\end{tabular}


Berdasarkan kedua komponen di atas, maka dijadikan dasar untuk penentuan tingkat optimal dari beragam pola agroforestri sebagai berikut;

Tabel 5. Tingkat optimal/kelayakan pola agroforestri

\begin{tabular}{lll}
\hline Kisaran Nilai & Kriteria & \multicolumn{2}{c}{ Keterangan } \\
\hline $1 . \quad 20-70$ & Tidak optimal & Prinsip praktik agroforestri yang \\
2. $>70-120$ & Cukup & baik adalah memiliki nilai \\
3. $>120-170$ & Baik & seimbang andara \\
4. $>170-200$ & Sangat baik & $\begin{array}{l}\text { pendapatan dan jumlah } \\
\text { cadangan karbon }\end{array}$ \\
\hline
\end{tabular}

\section{HASIL DAN PEMBAHASAN}

\section{Gambaran Responden Penelitian}

Umur responden teridentifikasi mulai pada umur 24-71 tahun. Sebagian besar terdistribusi pada interval umur 32-47 tahun. Dalam praktiknya, hak kelola lahan garapan di kawasan hutan, tidak murni dilakukan oleh petani yang terdaftar awal sebagaimana SK Bupati yang telah diterbitkan.Lahan kelola juga sudah dikelola oleh kerabat dalam hal ini bisa anak maupun menantu.Sehingga hal ini yang menyebabkan penggarap lahan terdapat banyak pada kisaran umum tersebut.

Responden memiliki pendidikaninterval yang cukup lebar, artinya responden teridentifkasi mulai dari yang tidak pernah sekolah sampai dengan sarjana. Sebagian besar SD (40\%) dan SMP (26\%).Menurut Karisma 2020 dalam Arkhama 2016 Tingkat pendidikan berkaitan dengan ilmu pengetahuan yang dimiliki, penguasaan teknologi, keterampilan, pola pikir dan informasi yang diperoleh. Ada dua orang sarjana yang telah terlibat dalam pengelolaan HKm. Kedua orang tersebut, menurut pendapat petani yang lain, termasuk sukses mengelola lahannya. Mereka yang berhasil inilah yang menjadi panutan atau kontak belajar bagi petani lainnya.

Seluruh responden memiliki pekerjaan utama sebagai petani hutan. Dengan demikian sebagian besar curahan waktu kerja dan penghasilan bergantung pada hasil hutan, terutama hasil hutan bukan kayu (HHBK). Namun demikian, tidak sepenuhnya penghasilan diperoleh dari hutan, mereka juga memiliki usaha-usaha sampingan untuk menambah penghasilannya, antara lain petani non hutan, peternak, pedagang dan serabutan.

Berdasarkan hasil penelitian, rata-rata luas garapan petani adalah 0,4 ha. Gambaran sebaran luas garapan lahan petani adalah sebagai berikut hal ini sesuai dengan data Ijin Usaha Pemanfaatan HKm Bupati Lombok Barat (2005), rata-rata luas 0,35 ha. Prinsip pembagian lahan adalah mengutamakan masyarakat miskin, antara lain yang tidak memiliki lahan kebun atau sawah, janda miskin dan para penduduk miskin yang bergantung pada sumber daya hutan.

\section{Identifikasi Pola Agroforestry}

Pola umum agroforestry adalah campuran dengan sistem acak.Artinya, dalam mengelola tanaman di lahannya, petani tidak mengatur tanaman dengan jarak tanam tertentu, atau menggunakan sistem jalur dan larikan tertentu, tetapi dilakukan dengan pola acak (Markum, et al., 2004).Petani memanfaatkan ruang yang ada untuk ditanami dengan beragam 
tanaman.Hal ini bisa terjadi karena sistem tanam untuk beragam jenis tanaman tidak dilakukan serentak, tetapi dengan bertahap.Oleh karena itu selain jenis tanaman yang beragam, umur tanaman juga beragam.Pola acak tersebut bisa dilihat dari salah satu contoh lahan petani yang ditransek (Gambar 1).

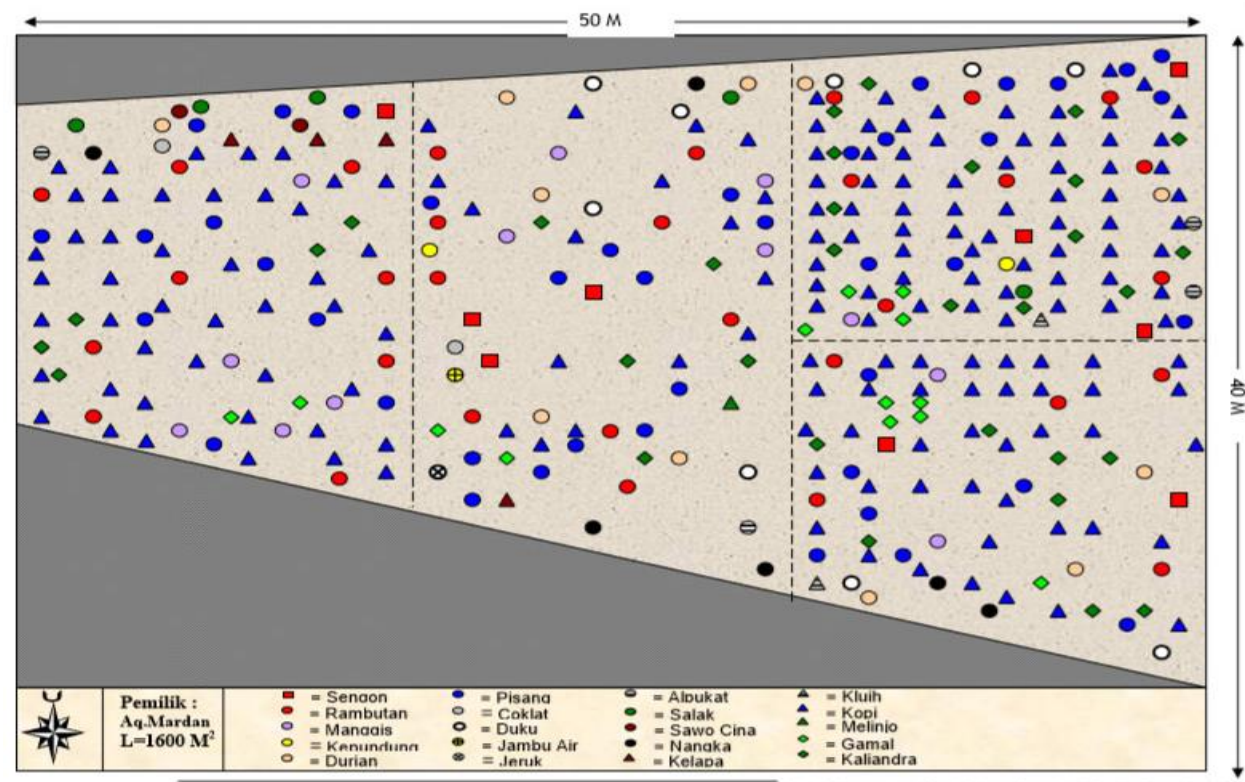

Gambar 1. Pola umum sistem agroforestry di Sesaot, pola acak

Secara umum kerapatan tanaman sebanyak 382 tanaman/ha, hal ini lebih kecil dibandingkan dengan hasil penelitian Markum et al (2013) yang menyebutkan ada sebanyak 600 tanaman/ha di kawasan hutan Sesaot. Berkurangnya kerapatan disebabkan oleh semakin berkurangnya tanaman kayu-kayuan dan tanaman lainnya akibat semakin besarnya tanaman MPTS, yang mengurangi kesempatan tumbuh tanaman di bawah naungan.

Secara umum jenis dan jumlah tanaman di Sesaot yang berukuran diameter pohon di atas $5 \mathrm{~cm}$ adalah sebagai berikut dipaparkan pada Tabel 6.

Tabel 6. Nama dan jumlah tanaman di lahan garapan petani

\begin{tabular}{llc}
\hline \multicolumn{1}{c}{ Nama Tanaman } & \multicolumn{1}{c}{ Nama Latin } & $\begin{array}{c}\text { Rata-rata Jumlah tanaman } \\
\text { (tanaman/ha) }\end{array}$ \\
\hline Tanaman MPTS & Durio zibethinus & 20 \\
\hline 1. Durian & Arenga pinnata & 8 \\
2. Aren & Garcinia mangostana & 41 \\
3. Manggis & Nephelium lappaceum & 24 \\
4. Rambutan & Theobroma cacao & 67 \\
5. Kakao & Coffea canefora var robusta & 48 \\
6. Kopi & Aleurites moluccana & 23 \\
7. Kemiri & Artocarpus integra & 5 \\
8. Nangka & Persea americana & 6 \\
9. Alpukat & Gnetum gnemon & 8 \\
10. Melinjo & & 33 \\
\hline Tanam Kayu & Swietenia macrophylla & 5
\end{tabular}




\begin{tabular}{llc}
\hline \multicolumn{1}{c}{ Nama Tanaman } & Nama Latin & $\begin{array}{c}\text { Rata-rata Jumlah tanaman } \\
\text { (tanaman/ha) }\end{array}$ \\
\hline Tanaman MPTS & & 7 \\
\hline 3. Dadap & Erytrina sp. & 3 \\
4. Suren & Toona sureni & 48 \\
\hline Tanama Lain & Musa paradisiaca & 37 \\
\hline 1. Pisang & Carica Papaya & 382 \\
\hline 2. Pepaya & & \\
\hline
\end{tabular}

Pengelompokkan pola agroforestry didasarkan atas dominasi jenis tanaman. Berdasarkan pola dominasi tanaman tersebut, telah ditemukan ada 4 pola agroforestry. Keempat pola agroforestry tersebut meliputi (1) pola agroforestry dominan kemiri, (2) pola agroforestry campuran, (3) pola agroforestry dominan mahoni dan (4) agroforestry sederhana.Keempat pola tersebut dapat dideskripsikan sebagai berikut (Tabel 7).

Tabel 7. Deskripsi Pola Agroforestry

\begin{tabular}{|c|c|c|c|}
\hline Pola Agroforestry & Deskripsi & $\begin{array}{c}\text { Jumlah } \\
\text { Responden }\end{array}$ & $\begin{array}{l}\text { Persentase } \\
\text { Responden } \\
(\%)\end{array}$ \\
\hline $\begin{array}{l}\text { 1. Pola } \\
\text { Agroforestry } \\
\text { Dominan } \\
\text { Kemiri }\end{array}$ & $\begin{array}{l}\text { Kemiri teridentifikasi lebih dominan berada } \\
\text { pada kisaran } 25 \text { - } 30 \text { pohon/ha. Selain tanaman } \\
\text { kemiri terdapat beberapa jenis tanaman lain } \\
\text { yaitu durian, kopi, cokelat, nangka, alpukat. } \\
\text { Dibawah tegakan kemiri cukup mencolok } \\
\text { dijumpai tanaman pisang. }\end{array}$ & 5 & 12 \\
\hline $\begin{array}{l}\text { 2. Pola } \\
\text { Agroforestry } \\
\text { Campuran }\end{array}$ & $\begin{array}{l}\text { Sebagian besar petani menerapkan pola ini, jenis } \\
\text { tanaman bervariasi dengan jumlah yang cukup } \\
\text { berimbang. Pola ini ditandai dengan banyaknya } \\
\text { tanaman buah-buahan dengan usia di atas lima } \\
\text { tahun. Pola ini paling diminati oleh petani } \\
\text { karena memberikan keuntungan ganda, hampir } \\
\text { sepanjang tahun mereka bisa memanen hasil } \\
\text { komoditi tertentu secara bergantian. }\end{array}$ & 27 & 64 \\
\hline $\begin{array}{l}\text { 3. Pola } \\
\text { Agroforestry } \\
\text { Dominan } \\
\text { Mahoni }\end{array}$ & $\begin{array}{l}\text { Pola ini paling sedikit, dan pohon mahoni } \\
\text { merupakan tegakan asli kawasan hutan, artinya } \\
\text { petani tidak menanam mahoni, tetapi } \\
\text { mengusahakan tanaman dibawah tegakan } \\
\text { mahoni, terutama kopi. Pola ini paling tidak } \\
\text { diminati, karena tutupan mahoni bisa sangat } \\
\text { rapat, sehingga menyisakan sedikit cahaya } \\
\text { matahari untuk tanaman di bawahnya. }\end{array}$ & 3 & 7 \\
\hline $\begin{array}{l}\text { 4. Pola } \\
\text { Agroforestry } \\
\text { Sederhana }\end{array}$ & $\begin{array}{l}\text { Pola ini diciriikan oleh sedikitnya tanaman } \\
\text { pohon (dibawah } 100 \text { tanaman/ha) namun } \\
\text { didominasi oleh tanaman pisang, pepaya, dan } \\
\text { jenis perdu seperti kacang merah (lebui). Petani } \\
\text { yang memiliki pola ini tidak banyak, bagi } \\
\text { mereka yang memiliki pola ini dikarenakan } \\
\text { menganggap hasil beberapa produk seperti } \\
\text { pisang dan pepaya cukup layak. Namun }\end{array}$ & 7 & 17 \\
\hline
\end{tabular}




\begin{tabular}{llcc}
\hline Pola Agroforestry & \multicolumn{1}{c}{ Deskripsi } & $\begin{array}{c}\text { Jumlah } \\
\text { Responden }\end{array}$ & $\begin{array}{c}\text { Persentase } \\
\text { Responden } \\
(\%)\end{array}$ \\
\hline & $\begin{array}{l}\text { demikian saat ini, sudah mulai } \\
\text { ditumpangsarikan dengan beberapa jenis MPTS, } \\
\text { sehingga selama 5 tahun lagi, diprediksikan } \\
\text { tanaman pisang dan pepaya akan semakin } \\
\text { tergusur dengan tanaman MPTS. }\end{array}$ & \\
\hline Jumlah & 42 & 100 \\
\hline
\end{tabular}

Pola agroforestry dominan kemiri dicirikan oleh menonjolnya beberapa ragam tanaman selain tanaman kemiri, yaitu tanaman kakao, manggis, kopi dan beberapa jenis buah-buahan. Salah satu kelebihan tanaman kemiri menurut petani adalah, meskipun kemiri memiliki lebar tajuk yang besar, tetapi masih memiliki ruang cahaya cukup untuk dapat tumbuh tananamtanaman pada strata yang lebih bawah. Sehingga dapat dicermati beberapa tanaman lain dapat tumbuh dengan baik di bawah tegakan kemiri. Pada pola agroforestry campuran terdapat beberapa tanaman yang menonjol yaitu kakao, kopi, manggis, durian dan rambutan dan aren. Beragam jenis tanaman tersebut selain memiliki kerapatan yang cukup tinggi, juga memiliki diameter pohon pada kisaran di atas $10 \mathrm{~cm}-30 \mathrm{~cm}$. Total kerapatan beragam tanaman di atas adalah 308 tan/ha untuk pola agrofoerstry dominan kemiri, dan 402 tan/ha untuk pola agroforestry campuran.

Perbedaan mencolok terjadi pada pola agroforestry dominan mahoni dan agroforestry sederhana. Pada agroforestry dominan mahoni, selain tanaman mahoni, tanaman yang lain relatif kecil jumlahnya. Tanaman yang masih dapat tumbuh di bawah tegakan mahoni adalah tanaman kopi, kakao, manggis dan rambutan. Namun karena naungan yang rapat menyebabkan pertumbuhan beragam jenis tanaman tersebut tidak optimal. Kerapatan tanaman di pola dominan mahoni ini sebanyak 255 tan/ha. (Gambar 2).

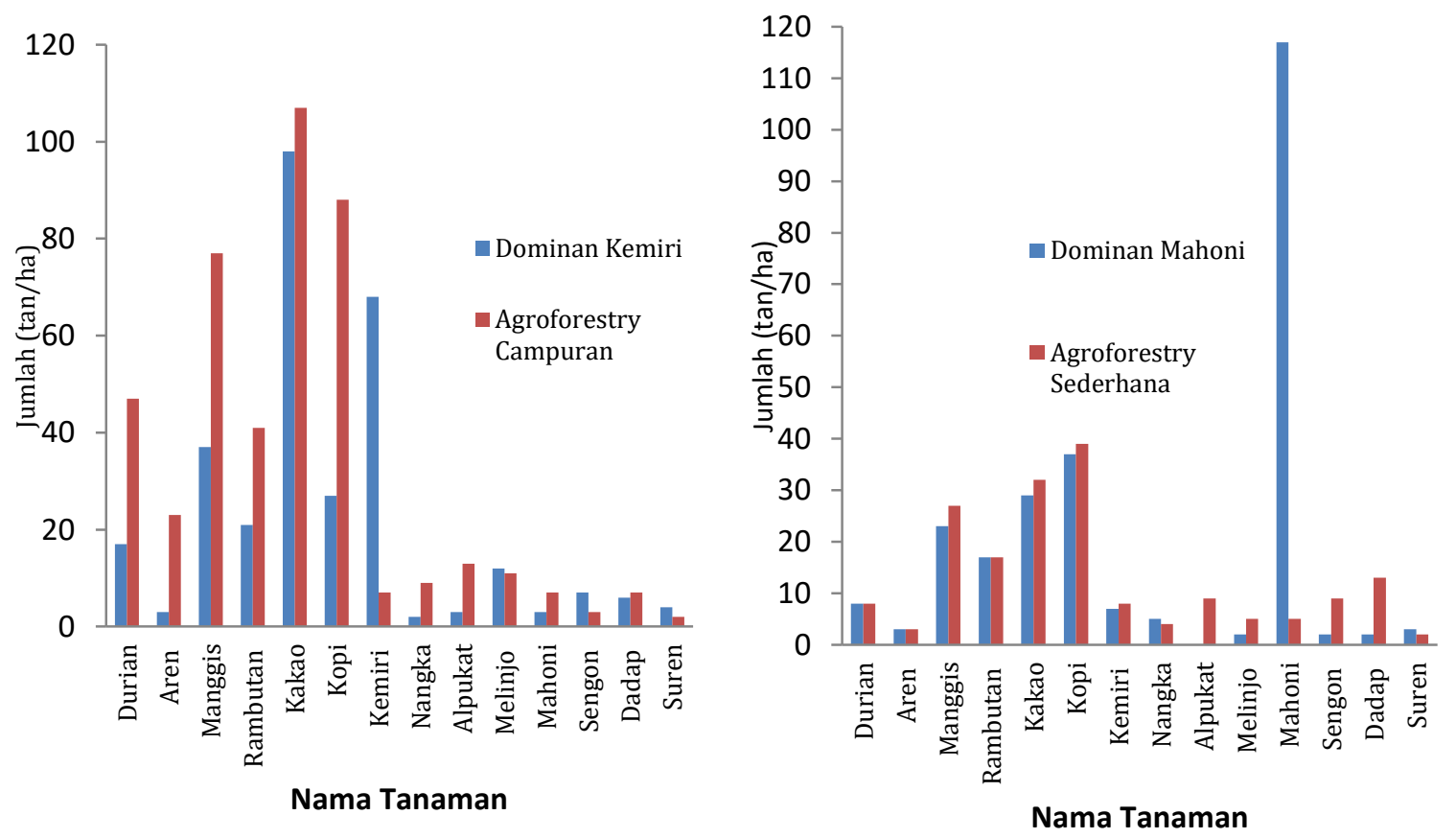

Gambar 2. Ragam dan jumlah tanaman pada berbagai pola agroforestry 
Pola agroforestry sederhana memiliki kerapatan total sebanyak 181 tan/ha, terdiri dari beragam tanaman yang cukup menonjol yaitu kopi, kako, rambutan dan manggis. Beberapa tanaman lain yang bisa ditemui antara lain dadap, sengon yang juga berfungsi sebagai penaung untuk tanaman kopi, kakao.

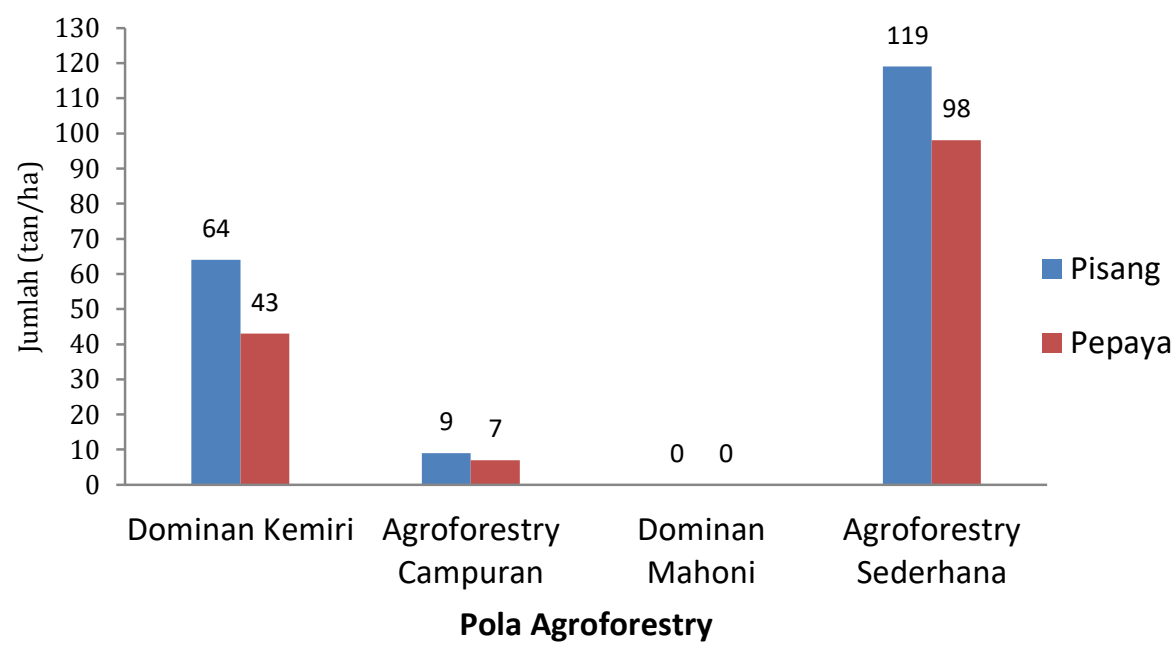

Gambar 3. Ragam dan jumlah tanaman pisang dan pepaya pada berbagai pola agroforestry

Selain beragam tanaman di atas, terdapat golongan tanaman lain yang cukup menonjol khususnya yang ada pada pola agroforestry sederhana, yaitu tanaman pisang dan pepaya. Tanaman pisang dan pepaya sangat diminati oleh petani pada saat awal mengelola lahan garapan Hutan Kemasyarakatan. Setidaknya ada 2 faktor penyebabnya, yaitu saat awal lahan masih cukup terbuka dan kondisi lahan subur, sehingga tanaman pisang dan pepaya dapat tumbuh baik dan produktif; Kedua tanaman pisang dan pepaya disebut sebagai tanaman penolong untuk menunjang ekonomi rumah tangga, karena dapat dipanen bulanan, daya serap pasarnya tinggi (Gambar 3).

\section{Analisis Pendapatan}

Beragam jenis tanaman tersebut di atas telah menggerakkan ekonomi penggarap dan masyarakat di KMPH pada khususnya dan Kawasan Hutan Sesaot pada umumnya. Jenis tanaman memiliki masa produksi yang berbeda, penggarap dapat memanen hasil secara harian, mingguan, bulanan dan musiman. Oleh karena itu bisa dikatakan masyarakat penggarap memiliki ketahanan pangan dan ekonomi yang cukup baik. Secara keseluruhan dalam konteks kawasan, HHBK tanaman khususnya buah-buahan memiliki potensi nilai ekonomi yang tinggi.

Berdasarkan gambaran produksi dan harga produksi Tabel.8, dapat diestimasi nilai penerimaan untuk berbagai produk setiap hektar dan dalam rentang satu tahun.Berdasarkan interval waktu produksi sebagaimana dijelaskan di atas, maka bagi petani yang memiliki keragaman tanaman tinggi, cenderung bisa memanfaatkan panen sepanjang waktu.Hasil analisis terhadap nilai produksi untuk setiap pola agrofrestry menunjukkan bahwa pola agrofoestri campuran memperoleh nilai produksi tertinggi, sedangkan nilai produksi terendah adalah pada pola agroforestry dominan mahoni. 
Tabel 8. Rata-rata produksi tiap tanaman dan harga produksi

\begin{tabular}{|c|c|c|c|c|}
\hline Nama Tanaman & $\begin{array}{c}\text { Rata-rata } \\
\text { Jumlah } \\
\text { Tanaman/ha }\end{array}$ & $\begin{array}{l}\text { Produksi rata-rata } \\
\text { (/tan/tahun) }\end{array}$ & $\begin{array}{c}\text { Satuan } \\
\text { Unit }\end{array}$ & $\begin{array}{c}\text { Harga Produksi } \\
\text { (Rp/unit) }\end{array}$ \\
\hline \multicolumn{5}{|l|}{ Tanaman MPTS } \\
\hline 1. Durian & 20 & 28 & Buah & 20.000 \\
\hline 2. Aren & 8 & 179 & Butir & 10.000 \\
\hline 3. Manggis & 41 & 7,5 & $\mathrm{Kg}$ & 12.500 \\
\hline 4. Rambutan & 24 & 30 & $\mathrm{Kg}$ & 6.000 \\
\hline 5. Kakao & 67 & 13,6 & $\mathrm{Kg}$ & 16.000 \\
\hline 6. Kopi & 48 & 4.5 & $\mathrm{Kg}$ & 22.000 \\
\hline 7. Kemiri & 23 & 50 & $\mathrm{Kg}$ & 10.000 \\
\hline 8. Nangka & 5 & 17 & buah & 8.000 \\
\hline 9. Alpukat & 6 & 47 & $\mathrm{Kg}$ & 4.000 \\
\hline 10. Melinjo & 8 & 12 & $\mathrm{Kg}$ & 15.000 \\
\hline \multicolumn{5}{|l|}{ Tanam Kayu } \\
\hline 1. Mahoni & 33 & - & - & - \\
\hline 2. Sengon & 5 & - & - & - \\
\hline 3. Dadap & 7 & - & - & - \\
\hline 4. Suren & 3 & - & $=$ & - \\
\hline \multicolumn{5}{|l|}{ Tanama Lain } \\
\hline 1. Pisang & 48 & 1 & Tandan & 29.000 \\
\hline 2. Pepaya & 37 & 17 & buah & 3.000 \\
\hline
\end{tabular}

Sumber. Data Primer, 2020.

Biaya yang dikeluarkan meliputi biaya pembibitan, pemeliharaan dan panen. Kebutuhan biaya untuk pemeliharaan kebun dilakukan saat kegiatan ngasor (mencangkul/membalikan tanah) yang dilakukan pada awalmusim hujan. Kegiatan ngasorbiasanya dilakukan sendiri oleh petani bersama anggota keluarga lainnya. Hanya sebagian kecil petani yang menggunakan tenaga kerja diluar keluarga dengan upah Rp.60.000/orang/hari. Alasannya, karena ada kesibukan lain, atau tidak ada anggota keluarga yang membantu. Berikut adalah gambaran nilai produksi, biaya dan pendapatan untukberbagai pola agroforestry (Gambar 4).

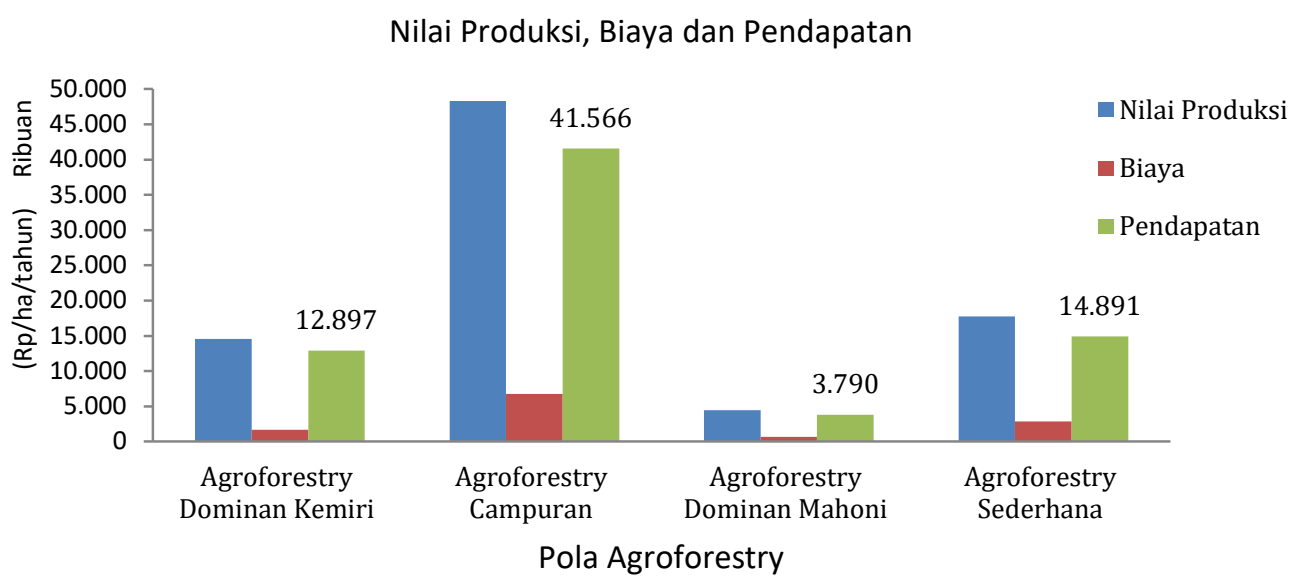

Gambar 4. Nilai produksi, biaya dan pendapatan pada berbagai pola agroforestry 
Jika merujuk pada standar kemiskinan Bank Dunia, untuk tidak disebut miskin sekurang-kurangnya US \$ 1 per orang/hari, maka apakah jumlah pendapatan tersebut di atas sudah dapat dikategorikan mampu mengentaskan kemiskinan rumah tangga? Berdasarkan gambar 4 di atas dapat dicermati bahwa pola agroforestry dominan mahoni belum mampu memenuhi standar kemiskinan petani. Dan jika harus dihitung, setiap rumah tangga petani terdiri atas 4 orang, maka hanya pola agroforestri campuran yang mampu mengentaskan keluarga dari kemiskinan.

\section{Analisis Cadangan Karbon}

Hasil penelitian menunjukkan bahwa cadangan karbon tertinggi terdapat pada pola agroforestry dominan mahoni, mencapai 136 ton/ha, dan yang terkecil pada agroforestry campuran. Faktor penentu utama jumlah cadangan karbon adalah besarnya diameter pohon dan berat jenis kayu. Diameter tanaman pada pola agroforstry dominan kemiri, agroforestry campuran dan dominan mahoni, sebagian besar terdiri dari tanaman dengan diameter diatas $20 \mathrm{~cm}$ (pohon), sedangkan pada agroforstry sederhana didominasi oleh tanaman diameter tiang. Pada semua pola agroforestry, jumlah cadangan karbon sebagian besar berasal dari diameter pohon. Rata-rata sebanyak $75 \%$ cadangan karbon disumbang dari cadangan karbon pada diameter pohon, sedangkan terkecil berasal dari cadangan karbon pancang $(6 \%)$ (Gambar 5).

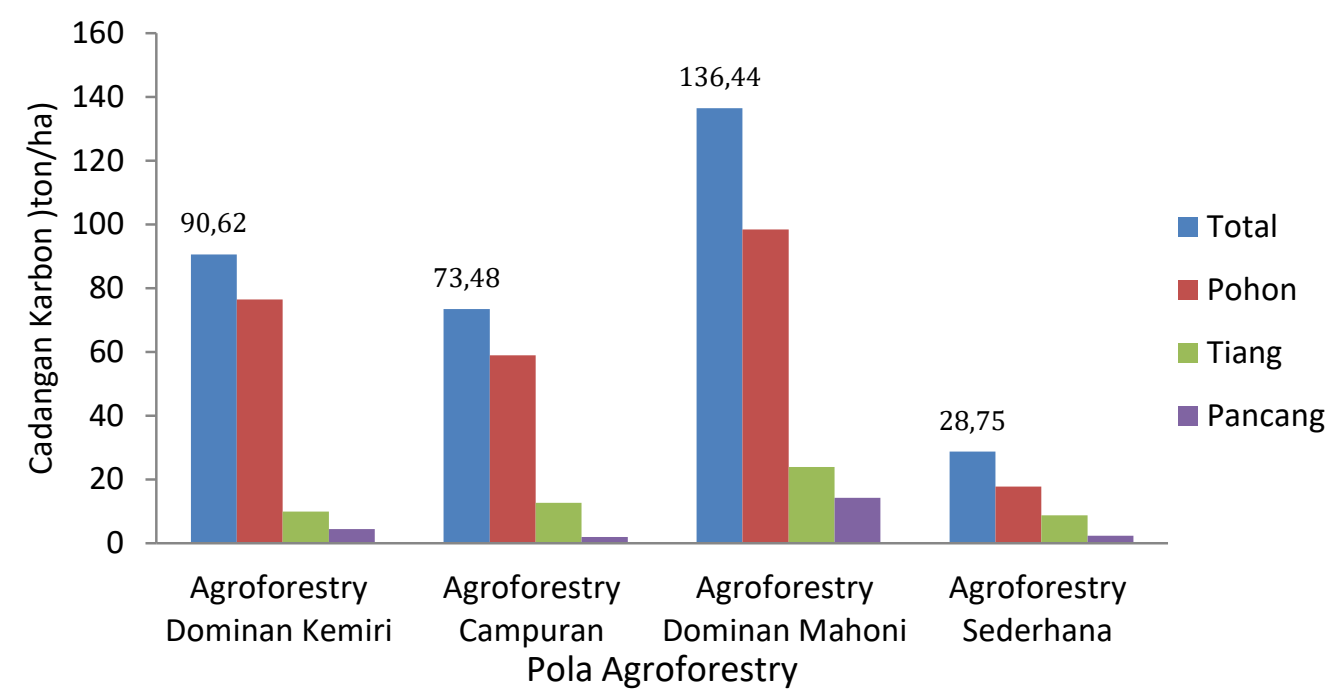

Gambar 5. Cadangan karbon pada berbagai pola agroforestry

Komposisi jumlah pohon lebih banyak dibandingkan dengan tanaman tiang maupun pancang, disebabkan praktik Perhutanan Sosial di Sesaot sudah dimulai sejak tahun 2000, dan mulai dilakukan pengayaan tanaman pada tahun 2005. Maka jika dicermati dari usia tanaman, berada pada kisaran 15-20 tahun, yang memungkinkan diameter tanaman sudah melebihi 20 m. Bahkan untuk tanaman mahoni, usia tanaman rata-rata melebihi 30 tahun. Komposisi jumlah cadangan karbon pada berbagai diameter tanaman disajikan pada Gambar 4.10 berikut. Hasil penelitian (Markum et al., 2013) di Kawasan Hutan Sesaot pada berbagai tutupan hutan menyebutkan hal yang sama, bahwa sebagian besar cadangan karbon berasal dari pohon. Dari jumlah cadangan karbon pada berbagai tutupan hutan di Kawasan Sesaot, 
sistem agroforestry multi strata telah memberikan kontribusi cadangan karbon pada kisaran $18 \%-23 \%$. Bisa disimpulkan bahwa, penerapan sistem agroforestry mampu memberikan sumbangan cadangan karbon yang cukup besar dalam perspektif cadangan karbon pada tingkat landscape, sebagaimana hal ini juga terjadi di beberapa tempat lain (Hairiah et al., 2006; Hairiah et al., 2020).

\section{Analisis Tingkat Optimal}

Analisis tingkat optimal dimaksudkan untuk mengetahui pola agroforestry mana yang paling sesuai, dengan mempertimbangkan kombinasi dua komponen utama yaitu pendapatan dan jumlah cadangan karbon. Kedua komponen tersebut mewakili dua aspek dalam pengelolaan kawasan hutan, yaitu ekonomi dan lingkungan.Pendapatan menggambarkan indikator ekonomi rumah tangga yang diperoleh dari hasil hutan bukan kayu. Cadangan karbon menggambarkan aspek lingkungan, karena dengan mengetahui cadangan karbon, bisa diestimasikan kondisi hutan, terutama berkaitan dengan besaran biomasa tanaman, tutupan hutan, Luas Bidang Dasar (LBD) dan kerapatan tanaman (Hairiah et al., 2008; Rahayu dan Harja, 2012).

Dari aspek pendapatan, perolehan skor tertinggi terdapat pada agroforestry campuran, atau termasuk dalam kategori sangat baik. Dengan nilai pendapatan Rp 41.566.05 /ha/tahun, jika diasumsikan setiap keluarga terdiri atas 4 orang, maka pendapatan yang diperoleh adalah Rp 28.865 per capita/hari, artinya rumah tangga mereka sudah berada di atas garis kemiskinan. Nilai skor pendapatan untuk beragam pola agroforestry adalah (Tabel 9).

Tabel 9. Skor pendapatan pada berbagai pola agroforestry

\begin{tabular}{lrcc}
\hline Pola Agroforestry & $\begin{array}{c}\text { Pendapatan } \\
\text { Rp/ha/tahun })\end{array}$ & Perolehan Skor & Kriteria \\
\hline 1. Dominan Kemiri & 12.897 .325 & 30 & Cukup \\
2. Agroforestry Campuran & 41.566 .050 & 100 & Sangat baik \\
3. Dominan Mahoni & 3.790 .450 & 10 & Buruk \\
4. Agroforestry Sederhana & 14.890 .542 & 30 & Cukup \\
\hline
\end{tabular}

Sedangkan pola agroforestry mahoni termasuk dalam kriteria buruk, karena pola tersebut belum mampu memenuhi standar minimal kemiskinan untuk 1 orang (Rp 15.000/orang/hari), yang minimal seharusnya sebesar $\mathrm{Rp} 5.400 .000 /$ tahun.Kondisi ini berbanding terbalik jika dilihat dari komponen cadangan karbon, karena pada pola dominan mahoni, memiliki skor tertinggi dibandingkan dengan pola yang lainnya (Tabel 10).

Tabel 10. Skor jumlah cadangan karbon pada berbagai pola agroforestry

\begin{tabular}{lrcc}
\hline Pola Agroforestry & $\begin{array}{c}\text { Cadangan Karbon } \\
\text { (ton/ha) }\end{array}$ & Perolehan Skor & Kriteria \\
\hline 1. Dominan Kemiri & 90.62 & 60 & Baik \\
2. Agroforestry Campuran & 73.48 & 60 & Baik \\
3. Dominan Mahoni & 136.44 & 100 & Sangat baik \\
4. Agroforestry Sederhana & 28.75 & 10 & Buruk \\
\hline
\end{tabular}


Dua kondisi tersebut kontradiktif, menjadi penting untuk mengetahui dua kombinasi yang kompromis dalam menjembatani dua kepentingan orientasi ekonomi dan lingkungan melalui penilaian skoring berikut (Tabel 11).

Tabel 11. Penilaian optimal praktik beragam pola agroforestry

\begin{tabular}{lcccc}
\hline Pola Agroforestry & $\begin{array}{c}\text { Pendapatan } \\
\text { (Rp/ha/tahun) }\end{array}$ & $\begin{array}{c}\text { Cadangan Karbon } \\
\text { (ton/ha) }\end{array}$ & $\begin{array}{c}\text { Jumlah } \\
\text { Skor }\end{array}$ & Kriteria \\
\hline 1. Dominan Kemiri & 30 & 60 & 90 & Cukup \\
2. Agroforestry Campuran & 100 & 60 & 160 & Baik \\
3. Dominan Mahoni & 10 & 100 & 110 & Cukup \\
4. Agroforestry Sederhana & 30 & 10 & 40 & Buruk \\
\hline
\end{tabular}

Berdasarkan hasil analisis skoring, pola agroforestry yang paling baik atau paling optimal diantara 4 pola yang ada adalah pola agroforestry campuran. Pola agroforestry campuran dinilai memenuhi syarat untuk mendukung penghasilan rumah tangga dan sekaligus pelestarian hutan. Meskipun nilai cadangan karbon tidak sebesar pada mahoni, tetapi jika dicermati dari kerapatan tanaman, dan keragaman tanaman yang ada, pola agroforestry dengan tanaman yang rapat bisa mempertahankan kestabilan lahan dalam hal ekonomi mikro, mengurangi limpasan permukaan dan sebagai penyangga keanekaragaman spesies tanaman (Nasi et al., 2002). Sebagaimana hasil penelitian Markum et al. (2013), bahwa praktik agroforestry yang baik dapat menekan limpasan permukaan sampai dengan 17 $\%$, dan bahkan bisa mendekati limpasan permukaan di hutan primer.

\section{Kesimpulan}

\section{KESIMPULAN}

Praktik Perhutanan Sosial dengan sistem agroforestry di Kawasan Hutan Sesaot telah diidentifikasi ada 4 pola agroforestry, yaitu pola agroforestry dominan kemiri, pola agroforerstry campuran, pola agroforestry dominan mahoni, dan pola agroforestry sederhana. Dari keempat pola tersebut diperoleh pendapatan masing-masing yaitu pola dominan kemiri (Rp 12.897.325), pola campuran ( $R p$ 41.566.05), pola dominan mahoni ( $R p$ 3.790.450) dan pola sederhana (Rp 14.890.542). Pola dominan mahoni memiliki jumlah cadangan karbon tertinggi (136 ton/ha), diikuti oleh dominan kemiri (91 ton/ha), pola campuran (74 ton/ha) dan pola sederhana (29 ton/ha). Berdasarkan dua komponen ekonomi dan cadangan karbon tersebut, kombinasi yang paling optimal adalah pola agroforestry campuran.Penerapan pola agroforestry campuran dinilai telah memenuhi prinsip=prinsip pengelolaan hutan yang memenuhi kriteria aspek ekonomi dan aspek lingkungan

\section{Saran}

Sebagai tindak lanjut hasil penelitian, disarankan pentingnya dua kegiatan yaitu pemberdayaan masyarakat dan penelitian lanjutan.Kegiatan pemberdayaan masyarakat yang diperlukan adalah memberikan pelatihan tentang sistem budidaya yang lebih baik dalam upaya meningkatkan kualitas produk hasil hutan non kayu sehingga lebih kompetitif di pasar.Kegiatan penelitian lanjutan yang diperlukan adalah, pentingnya diketahui daya ketahanan dan kerentanan aspek lingkungan pada berbagai pola agroforestry yang telah 
diidentfikasi.Aspek lingkungan yang dimaksud meliputi Bahan Organik Tanah, limpasan permukaan, struktur tanah, dan keanekaragaman hayati.

\section{Ucapan Terima Kasih}

Atas telah terselenggaranya penelitian, peneliti mengucapkan terima kasih kepada Ketua Forum Masyarakat Hutan Sesaot dan Ketua Kelompok Masyarakat Pelestari Hutan Sesaot yang telah membantu mengkoordinasikan kegiatan penelitian. Terima kasih juga disampaikan kepada Universitas Mataram atas dana yang diberikan melalui penelitian skim Penelitian PNBP tahun 2020 melalui LPPM Unram.

\section{DAFTAR PUSTAKA}

Arifin, 2001. Estimasi penyimpanan C pada berbagai sistem penggunaan lahan di Kecamatan Ngantang Malang. Jurusan Tanah Fakultas Pertanian Universitas Brawijaya 61p.

Cabezas, P.P., K. Nathaniel, 2008. Reducing emissions from deforestation and forest degradation in developing countries (REDD): Implications for the carbon market. Environmental Defense Fund. 13p

Fahmudin A., 2004. Environmental services of agriculture and farmer's practices worth rewarding. in Proceedings. Hidrological impacts of forest, agroforestri and upland copping as a basic for rewarding environmental service providers in Indonesia. World Agroforestry Centre (ICRAF). p37-49

Faisal, S. 2010. Format-Format Penelitian Sosial. Pt Raja Grafindo Persada. Jakarta.

Hairiah K., J. Arifin, C. Prayogo, Widianto and Sunaryo. 2002. Prospek agroforestri berbasis kopi untuk cadangan karbon. Journal of Agrivita 12(2): 145-150

Hairiah, K, Meine van Noordwijkb, Rika Ratna Saria, Danny Dwi Saputraa, Widiantoa, Didik Suprayogoa, Syahrul Kurniawana, Cahyo Prayogoa, Sikstus Guslid Hairiah, 2020. Soil carbon stocks in Indonesian (agro) forest transitions: Compaction conceals lower carbon concentrations in standard accounting. Journal of Agriculture, Ecosystems and Environment. 294 (106879).

Hairiah, K., D. Suprayogo, Widianto, Berlian, E. Suhara, A. Mardiastuning, R.H. Widodo, C. Prayogo, S. Rahayu, 2004. Alih guna lahan hutan menjadi lahan agroforestry berbasis kopi: Ketebalan seresah, populasi cacing tanah dan makroporositas tanah. Journal of Agrivita 26 (1): 68-80

Hairiah, K., S. Rahayu dan Berlian, 2006. Layanan lingkungan agroforestri berbasis kopi: cadangan karbon dalam biomassa pohon dan bahan organik tanah (studi kasus dari Sumberjaya, Lampung Barat). Journal of Agrivita 28 (3): 298-309

Hairiah, K., Subekti Rahayu, 2011. Petunjuk praktis pengukuran karbon tersimpan di berbagai macam penggunaan lahan. Word Agroforestry centre, ICRAF Southeast Asia. p77

Hairiah, K., Widianto dan D. Suprayogo, 2008. Adaptasi dan Mitigasi Pemanasan Global: Bisakah agroforestri mengurangi reskio longsor dan emisi gas rumah kaca? Kumpulan makalah INAFE. Pendidikan agroforestri sebagai strategi menghadapi perubahan iklim global: p42-62 
IFCA, 2008. REDD methodology and strategies summary for policy makers. p1-13

Keputusan Bapati Lombok Barat Nomor 2130/65/Dishut/2009 tentang Izin Pemanfaatan Hutan Kemasyarakatan (IUPHKm) di Kawasan Hutan Sesaot, Lombok Barat.

Markum, Budhy Setiawan, Rahmat Sahbani, 2014. Hutan Kemasyarakatan, sebuah ikhtiar mewujudkan hutan lestari masyarakat sejahtera. BPDAS Dododkan Moyosari NTB. 166p.

Markum, E. Arisoesilaningsih, D. Suprayogo, K. Hairiah. 2013. Contribution of agroforestry system in maintaining carbon stocks and reducing emissions rate at Jangkok watershed, Lombok Island. Journal of Agrivita 35(1): 54-63

Markum, E. Arisoesilaningsih, D. Suprayogo, K. Hairiah, 2014. Plant species diversity in relation to carbon stocks at jangkok watershed, lombok island. Journal of Agrivita 35(3):207-217

Markum, Muktar, Kurniawan, 2004. Studi penerapan model agroforestry di Sekitar Sumber mata air di Lombok Barat. LP3ES, Jakarta. 93p.

Muktar, 2011. Pengelolaan program HKm berbasis kearifan lokal: studi kasus di kawasan hutan lindung Sesaot. Thesis. Program studi pengeolaan sumber daya alam dan lingkungan, Universitas Brawijaya Malang. 169p

Nair, 1993. An Introduction to agroforestry. Kluwer AcademicPublisher, The Nederlands. $245 \mathrm{pp}$

Nasi, R., S. Wunder and A. J.J. Campos., 2002. Forest ecosystem services: can they pay our way out of deforestation? A discussion paper prepared for the GEF for the forestry roundtable to be held in conjunction with the UNFF II. Costa Rica.

Peraturan Menteri Lingkungan Hidup dan Kehutanan No. P83/MENLHK/SETJEN/KUM.1/10/2016 Tentang Perhutanan Sosial. Berita Lembaran Negara Republik Indonesia Tahun 2016 Nomor 1663

Prayitno, W. dan Wasmat, 2001. Flora dan fauna kawasan Rinjani. WWF Nusa Tenggara dan Taman Nasional Gunung Rinjani. Laporan Hasil Penelitian. 119p

Rahayu, S. dan D. Harja, 2012. Dinamika keanekaragaman hayati tumbuhan dan cadangan karbon pada skala landsekap dan tutupan lahan. Paper, Word Agroforestry Centre, ICRAF. $14 \mathrm{p}$

Soekartawi, 2005. Prinsip-Prinsip dasar ekonomi pertanian, toeri dan aplikasinya. PT Raja Grafindo Persada, Jakarta.

Suradiredja D.Y., Andi P., Markum, Wiji Johar S., M Ridha Hakim, 2018. Menoleh jalan panjang hutan kemasyarakatan. Catatan perjalanan tiga dasawarsa program Hutan Kemasyarakatan di Pulau Lombok. WWF Indonesia. 199p.

Tjakrawarsa, G., G. Suardika, A.C. Dining, Syafrudin, S. Fajar, W. Basuki, A. Jaswadi., Markum, 2009. Studi analisis hidrologis dan perubahan tutupan lahan kawasan Gunung Rinjani, Lombok. WWF. 87p

Tratib, 2011. Studi penilaian kondisi DAS dan implikasinya terhadap fluktuasi debit sungai (Studi kasus pada sub DASJangkok Pulau Lombok). Thesis. Fakultas Teknik Universitas Brawijaya. 193p 
van Noordwijk M., A. Fahmudin, D. Suprayogo, K. Hairiah, G. Pasya, Bruno, Farida, 2004. Peranan agroforestri dalam mempertahankan fungsi hidrologi Daerah Aliran Sungai (DAS). Agrivita $26(1): 1-8$ 